\title{
Primary Analysis of the Risk Factors for Severity and Mortality in COVID- 19 Patients in Uzbekistan
}

\author{
Visolatkhon Sharipova, Khikmat Anvarov, Abdusalom Abdurakhmanov, Azamat Alimov,
} Nurbek Iskhakov

Republican Research Centre of Emergency Medicine, Tashkent, Uzbekistan. DOI: https://doi.org/10.24321/0019.5138.202145

\section{I $\quad \mathbf{N} \quad \mathbf{F} \quad \mathbf{O}$}

\section{Corresponding Author:}

Azamat Alimov, Republican Research Centre of Emergency Medicine, Tashkent, Uzbekistan. E-mail Id:

azamat.kh.alimov@gmail.com

Orcid Id:

https://orcid.org/0000-0001-5777-6166

How to cite this article:

Sharipova V, Anvarov K, Abdurakhmanov A, Alimov A, Iskhakov N. Primary Analysis of the Risk Factors for Severity and Mortality in COVID-19 Patients in Uzbekistan. J Commun Dis. 2021;53(3):104-111.

Date of Submission: 2021-07-12

Date of Acceptance: 2021-09-13

\section{$\begin{array}{llllllll}\mathbf{A} & \mathbf{B} & \mathbf{S} & \mathbf{T} & \mathbf{R} & \mathbf{A} & \mathbf{C} & \mathbf{T}\end{array}$}

\begin{abstract}
A retrospective analysis of 561 patients with confirmed COVID-19 was performed to determine the risk factors for severity and mortality which could predict the disease outcome in early stages. Patients were divided into 4 groups in accordance with disease severity: mild, moderate, severe and critical. And initial clinical and laboratory parameters of patients at admission were studied. The age of severe and deceased patients was significantly higher than patients with mild and moderate course $(p=0.003)$. Patiens with severe disease and fatal outcome had higher incidence of concomitant diseases compared to patients with mild and moderate course $(p=0.01)$. The time passed from onset of first symptoms and hospital admission was shorter in patients with mild and moderate disease than patients with severe and critical disease $(p=0.0001)$. The leukocytosis, significant lymphopenia $(p=0.0001)$, high $D$-dimer and ferritin levels were associated with severe disease. Male gender, old age, presence of concomitant diseases should be considered as risk factors for severe course and death at COVID-19.
\end{abstract}

Keywords: Coronavirus Infection, Mortality Risk Factors, Severe Course, Mortality Prediction

\section{Introduction}

A new type of coronavirus, SARS-CoV-2 has led to a worldwide COVID-19 pandemic (Coronavirus Disease 2019). By the end of the spring of 2021, the number of confirmed cases of infection reached 170 million people and the disease caused more than 3.5 million deaths worldwide. ${ }^{1}$ The clinical manifestations of this disease are very wide and diverse: from asymptomatic carriers to symptoms of acute upper respiratory tract infection and sometimes severe acute respiratory failure and death. ${ }^{2}$ Although COVID-19 has a lower mortality rate than previously known coronavirus infections SARS-CoV or MERS-CoV (Middle East respiratory syndrome), the absolute number of deaths is high due to the high contagiousness of the infection. Various risk factors potentially affecting the susceptibility to infection and the severity of the disease are discussed, but it is not completely clear what factors determine the clinical course and disease outcome. ${ }^{3}$ Many studies suggest elderly age, presence of comorbidities, a high SOFA score, high D-dimer levels as markers of poor prognosis. ${ }^{4}$ The first case of COVID-19 in Uzbekistan was registered on March 15,2020 . As most of countries Uzbekistan also adopted restrictive epidemiologic measures to control the spreading the disease and specialized clinics have been organized and deployed for the treatment of COVID-19 patients. For more than a year of pandemic there are nearly 100 thousand registered cases of infection and nearly 700 
deaths. ${ }^{5}$ We aimed to determine the clinical, demographic and laboratory parameters which can predict the disease severity and mortality among Uzbekistan population.

\section{Materials and Methods}

This retrospective study includes 561 patients with confirmed COVID-19, treated at the Republican Research Center of Emergency Medicine (RRCEM) from July 2020 to September 2020. Patients were divided into 4 groups in accordance with disease severity: mild, moderate, severe and critical. Criteria for disease severity are given in Table 1.

Patient history and clinical data were used to determine the presence of concomitant diseases (such as hypertension, overweight or obesity, pre-existing respiratory or cardiovascular diseases, chronic kidney disease). Early symptoms, the time of the first visit to the doctor and the time of hospitalization were evaluated. Body mass index (BMI) $\geq 30 \mathrm{~kg} / \mathrm{m}^{2}$ was determined as obesity. Diabetes mellitus was determined based on medical history, medication intake, blood sugar and $\mathrm{HbA} 1 \mathrm{c}$ values $\geq 6.5 \%$. Fever days were defined as the time from the onset of the fever to the last documented value above $38.5^{\circ} \mathrm{C}$. Hemodynamic parameters (pulse, heart rate, non-invasive blood pressure), respiratory rate (RR) and oxygen saturation $\left(\mathrm{SpO}_{2}\right)$ were also measured. The number of neutrophilic leukocytes and lymphocytes, the parameters of coagulation, as well as the levels of C-reactive protein (CRP), ferritin and D-dimer were determined in the blood tests.

Table I.Criteria for Classification of Disease Severity

\begin{tabular}{|c|c|c|c|c|}
\hline \multirow{2}{*}{ Parameter } & \multicolumn{4}{|c|}{ Severity } \\
\hline & Mild & Moderate & Severe & Critical \\
\hline Clinical signs & $\begin{array}{c}\text { Sore throat, } \\
\text { nasal congestion, } \\
\text { unproductive cough, } \\
\text { malaise, myalgia, } \\
\text { hypoosmy }\end{array}$ & $\begin{array}{l}\text { Shortness of breath } \\
\text { during regular physical } \\
\text { activity, chestpain, } \\
\text { unproductive cough, } \\
\text { headache, malaise, } \\
\text { myalgia, loss of } \\
\text { appetite }\end{array}$ & $\begin{array}{l}\text { unproductive cough, } \\
\text { dyspnea and shortness } \\
\text { of breath at rest, } \\
\text { headache, malaise, } \\
\text { myalgia, loss of } \\
\text { appetite, anorexia, } \\
\text { nausea and vomiting, } \\
\text { agitation. }\end{array}$ & $\begin{array}{l}\text { Severe respiratory } \\
\text { failure, ARDS, } \\
\text { advanced } \\
\text { respiratory } \\
\text { support required, } \\
\text { septic shock, } \\
\text { multiorgan failure }\end{array}$ \\
\hline $\begin{array}{c}\text { Body } \\
\text { temperature }\end{array}$ & $\begin{array}{c}\text { episodic }<38.5^{\circ} \mathrm{C} \text { less } \\
\text { than } 3 \text { days }\end{array}$ & $>38.5^{\circ} \mathrm{C} 4-5$ days & $>38.5^{\circ} \mathrm{C}$ & $\begin{array}{c}\text { Persistent }>38.5 \\
{ }^{\circ} \mathrm{C}\end{array}$ \\
\hline $\mathrm{RR}$ & $<22$ & $\geq 22$ & $>24$ & $\geq 30$ \\
\hline $\mathrm{HR}$ & $60-90$ & $91-100$ & $\begin{array}{c}<120 \text { or new oncet } \\
\text { arrythmia }\end{array}$ & $\begin{array}{c}>120 \text { or new } \\
\text { oncet arrythmia }\end{array}$ \\
\hline $\begin{array}{c}\mathrm{SpO}_{2} \text { in a room } \\
\text { air }\end{array}$ & $\geq 94 \%$ & $93 \%$ & $\leq 92 \%$ & $\leq 80 \%$ \\
\hline $\begin{array}{c}\text { Lung } \\
\text { involvement } \\
\text { level on } \mathrm{CT}\end{array}$ & СТ 0 and 1 & CT 1 and 2 & CT 2 and 3 & CT 4 \\
\hline
\end{tabular}

ARDS - acute respiratory distress syndrome, RR - respiratory rate, HR - heart rate, CT - computed tomography

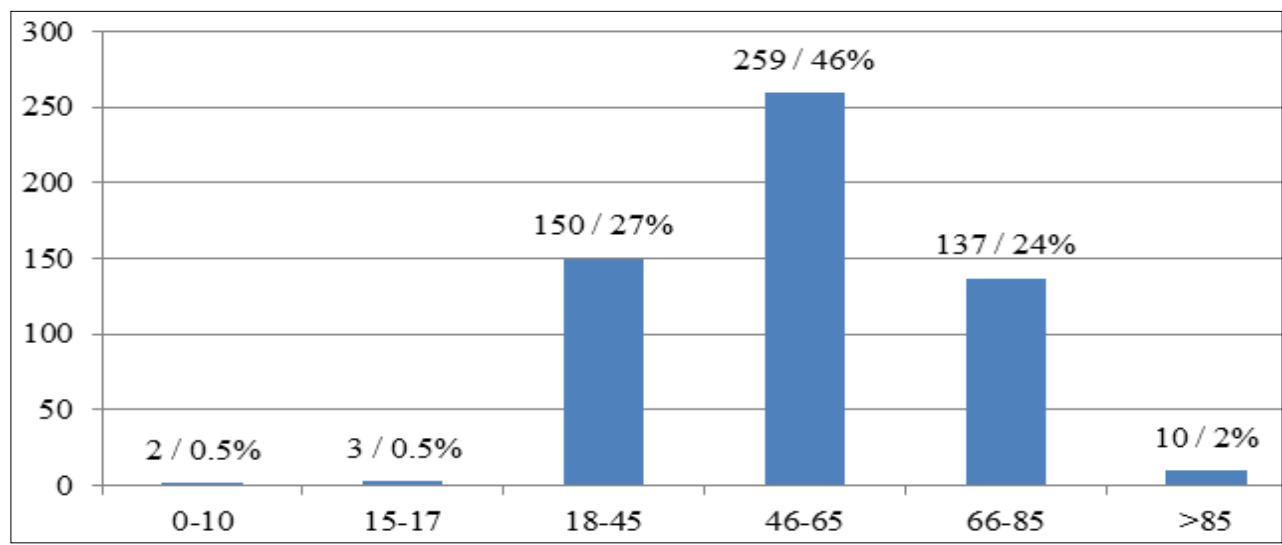

Figure I.Distribution of Patients by Age 
Table 2.Initial Data of Patients

\begin{tabular}{|c|c|c|c|c|c|}
\hline Parameters & $\begin{array}{c}\text { Mild } \\
\mathbf{n}=\mathbf{7 3}\end{array}$ & $\begin{array}{c}\text { Moderate } \\
\mathbf{n = 3 6 0}\end{array}$ & $\begin{array}{c}\text { Severe } \\
\mathbf{n}=89\end{array}$ & $\begin{array}{c}\text { Critical } \\
\mathbf{n}=\mathbf{3 9}\end{array}$ & $\mathbf{P}$ \\
\hline Mean age, years & $51.2 \pm 7.1$ & $53.7 \pm 7.3$ & $57.0 \pm 7.6$ & $70.8 \pm 8.4$ & 0.2 \\
\hline Male, \% & $37(50.7 \%)$ & $174(48.3 \%)$ & $55(61.8 \%)$ & $25(64.1 \%)$ & $>0.05$ \\
\hline $\begin{array}{c}\text { The presence of } \\
\text { concomitant diseases }\end{array}$ & $46(63.0 \%)$ & $250(69.4 \%)$ & $68(76.4 \%)$ & $35(89.7 \%)$ & 0.003 \\
\hline Smoking & $7(9.6 \%)$ & $49(13.6 \%)$ & $24(27 \%)$ & $12(30.8 \%)$ & $>0.05$ \\
\hline $\begin{array}{c}\text { Time from the onset } \\
\text { of the disease to } \\
\text { treatment, days }\end{array}$ & $6.4 \pm 2.5$ & $7.1 \pm 2.7$ & $8.4 \pm 2.9$ & $9.5 \pm 3.1$ & $>0.05$ \\
\hline BMI, kg/m 2 & $27.2 \pm 5.2$ & $28.3 \pm 5.3$ & $31.5 \pm 5.6$ & $28.3 \pm 5.3$ & $>0.05$ \\
\hline
\end{tabular}

Note: The data presented as an absolute number and percentage, or as a mean and standard deviations. BMI - body mass index.

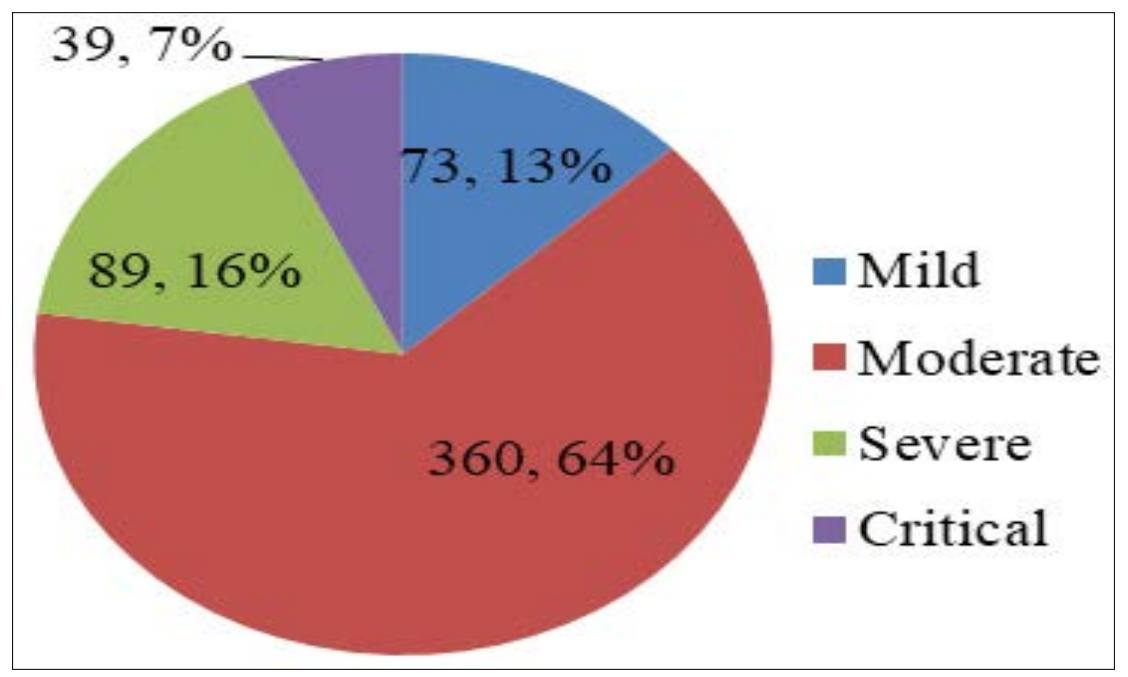

Figure 2.Distribution of Patients According to the Disease Severity

The data was analyzed using MS Excel 2010 (Microsoft) and MedCalc 20.5. (MedCalc Software Ltd). The data have been presented as a mean with standard deviation. The quantitative data were checked for the normal distribution using Kolmogorov-Smirnov test. In the case of a normal distribution to compare the data a one-way ANOVA was used. Otherwise, the Mann-Whitney-Wilcoxon criterion was used. Categorical variables were checked by Pearson's chi-squared test. Statistical significance was assumed for a value of $p<0.05$.

\section{Results}

$522(93.1 \%)$ of 561 patients treated at the RRCEM were discharged and 39 (6.9\%) died. 288 patients were males (51\%) and 273 females (49\%). Mean age of patients was $54.0 \pm 7.3$ years. The distribution of patients by age is shown in Figure 1.

The majority of patients [360 (64\%)] had a moderate-severe form of the disease. The distribution of patients according to the disease severity is presented in Figure 2.
The initial data of patients depending on the clinical course severity are shown in Table 2.

When analyzing the data obtained, we noticed that the age of patients in the groups with mild and moderate disease did not differ statistically significantly $(p=0.2)$, whereas the age of patients who had severe disease and/or a fatal outcome was significantly higher compared to patients with a mild disease $(p=0.003)$. The distribution of patients by gender was uniform, but there were more men among patients with severe and extremely severe course and fatal outcome, although the difference was statistically unreliable.

The frequency of concomitant diseases in all groups was quite high, but in the groups with a severe course and a fatal outcome, their frequency was significantly higher $(p=0.01)$. Patients with mild and moderate course were addressed earlier than patients with severe and extremely severe courses $(p=0.0001)$. Clinical symptoms also differed between the groups (Table 3).

When analyzing the clinical manifestations of the disease, 
we found that the average body temperature at admission in patients with mild and moderate course was subfebrile, while in the group of severe and extremely severe course, it reached febrile figures. The symptoms were dominated by headache and muscle pain, which were determined in the majority of patients in all groups and in almost all patients with an extremely severe course. The next significant signs of severe and extremely severe course were oxygen saturation $(88.2 \pm 9.2$ and $73.4 \pm 8.5 \%$ in severe and extremely severe patients versus $92.5 \pm 9.6$ and $94.2 \pm 9.7 \%$ in mild and moderate severe patients) and HR (86.0 \pm 9.3 and $85.1 \pm 9.2$ beats per minute in mild and moderate severe patients and $95.2 \pm 9.2$ and $101.8 \pm 9.0$ beats per minute in severe and extremely severe patients; $p=0.003$ ).
The indicators of blood tests were important in assessing the severity of the course: a general blood test with the count of leukocyte types and indicators of the blood coagulation system (Table 4 ).

In blood tests, attention is drawn to the dependence of some indicators on the severity of the disease. For example, the number of white blood cells significantly increased in patients with severe and extremely severe course compared with mild and moderate-severe course. At the same time, the increase in leukocytosis was followed by a significant decrease in the percentage of lymphocytes ( $p=0.0001)$. Attention is also drawn to the significant increase in ferritin and D-dimer values (Figure $3 \mathrm{~b}$ and $\mathrm{c}$ ), depending on the severity of the disease $(p=0.0001)$.

Table 3.Initial Clinical Characteristics of Patients at Admission

\begin{tabular}{|c|c|c|c|c|c|}
\hline Parameters & $\begin{array}{c}\text { Mild } \\
\mathbf{n}=73\end{array}$ & $\begin{array}{c}\text { Moderate } \\
\mathbf{n = 3 6 0}\end{array}$ & $\begin{array}{c}\text { Severe } \\
\mathbf{n = 8 9}\end{array}$ & $\begin{array}{c}\text { Critical } \\
\mathbf{n}=39\end{array}$ & $\mathbf{P}$ \\
\hline $\begin{array}{c}\text { Body temperature at } \\
\text { admission, } \mathrm{C}^{\circ}\end{array}$ & $37.4 \pm 6.1$ & $37.9 \pm 6.2$ & $38.2 \pm 6.2$ & $38.8 \pm 6.2$ & $>0.05$ \\
\hline Temperature $>38.0 \mathrm{C}^{\circ}, \mathrm{n}(\%)$ & $22(30.1 \%)$ & $163(45.3 \%)$ & $44(49.4 \%)$ & $21(53.8 \%)$ & $>0.05$ \\
\hline Headache, $\mathrm{n}(\%)$ & $44(60.3 \%)$ & $240(66.7 \%)$ & $78(87.6 \%)$ & $39(100 \%)^{*}$ & 0.0001 \\
\hline Muscle pain, $\mathrm{n}(\%)$ & $32(43.8 \%)$ & $175(48.6 \%)$ & $58(65.2 \%)$ & $39(100 \%)^{*}$ & 0.0001 \\
\hline Loss of smell and taste, $\mathrm{n}(\%)$ & $19(26 \%)$ & $82(22.8 \%)$ & $16(18 \%)$ & $25(64.1 \%)$ & $>0.05$ \\
\hline Dyspnea, $\mathrm{n}(\%)$ & $44(60.3 \%)$ & $307(85.3 \%)$ & $88(98.9 \%)$ & $39(100 \%)$ & $>0.05$ \\
\hline Saturation (SpO $), \%$ & $92.5 \pm 9.6$ & $94.2 \pm 9.7$ & $88.2 \pm 9.2$ & $73.4 \pm 8.5^{*}$ & 0.01 \\
\hline HR, per min. & $86.0 \pm 9.3$ & $85.1 \pm 9.2$ & $95.2 \pm 9.2$ & $101.8 \pm 9.0^{*}$ & 0.003 \\
\hline SBP, mm. Hg. & $124.5 \pm 11.0$ & $120.5 \pm 11.0$ & $121.7 \pm 11.0$ & $106.6 \pm 10.3^{*}$ & $>0.05$ \\
\hline
\end{tabular}

Note: The data presented as an absolute number and percentage, or as a mean and standard deviations. HR - heart rate, SBP - systolic blood pressure. ${ }^{*}$ p $<0.05$ - compared to the group of patients with mild and moderate disease.

Table 4.Initial Indicators of Blood Tests

\begin{tabular}{|c|c|c|c|c|c|}
\hline Parameters & $\begin{array}{c}\text { Mild } \\
\mathbf{n}=73\end{array}$ & $\begin{array}{c}\text { Moderate } \\
\mathbf{n = 3 6 0}\end{array}$ & $\begin{array}{c}\text { Severe } \\
\mathbf{n = 8 9}\end{array}$ & $\begin{array}{c}\text { Critical } \\
\mathbf{n}=39\end{array}$ & $\mathbf{P}$ \\
\hline Hemoglobin, g/l & $127.8 \pm 11.3$ & $123.9 \pm 11.1$ & $128.5 \pm 11.3$ & $125.7 \pm 11.2$ & $>0.05$ \\
\hline WBC, thousand per $\mathrm{mm}^{3}$ & $6.7 \pm 2.6$ & $6.9 \pm 2.6$ & $8.5 \pm 2.9$ & $8.5 \pm 2.9$ & $>0.05$ \\
\hline Platelets, thousand per $\mathrm{mm}^{3}$ & $235.0 \pm 15.3$ & $215.9 \pm 14.7$ & $287.0 \pm 17.0$ & $235.9 \pm 15.3$ & $>0.05$ \\
\hline Lymphocytes, \% & $24.2 \pm 4.9$ & $20.3 \pm 4.5$ & $14.3 \pm 3.8$ & $12.5 \pm 3.5^{*}$ & 0.0001 \\
\hline Neutrophils, \% & $68.5 \pm 8.3$ & $71.4 \pm 8.5$ & $75.6 \pm 8.7$ & $75.1 \pm 8.6$ & $>0.05$ \\
\hline ESR, $\mathrm{mm} / \mathrm{h}$ & $20.8 \pm 4.5$ & $23.6 \pm 4.9$ & $24.4 \pm 4.9$ & $28.3 \pm 5.3$ & $>0.05$ \\
\hline CRP, $\mathrm{mg} / \mathrm{mL}$ & $31.0 \pm 5.5$ & $23.3 \pm 4.8$ & $25.8 \pm 5.1$ & $45.1 \pm 6.6$ & $>0.05$ \\
\hline D-dimer, $\mathrm{ng} / \mathrm{mL}$ & $574.4 \pm 23.9$ & $607.5 \pm 24.7$ & $1709.0 \pm 41.7 *$ & $2473.2 \pm 48.9 *$ & 0.0001 \\
\hline Ferritin, $\mu \mathrm{r} / \mathrm{mL}$ & $227.7 \pm 14.9$ & $320.1 \pm 17.9$ & $763.3 \pm 27.7 *$ & $1305.2 \pm 35.9 *$ & 0.0001 \\
\hline PT, $\%$ & $78.5 \pm 8.8$ & $80.8 \pm 8.9$ & $80.4 \pm 9.0$ & $75.8 \pm 8.7$ & $>0.05$ \\
\hline Fibrinogen, $\mathrm{mg} \%$ & $490.8 \pm 21.9$ & $603.5 \pm 24.5$ & $887.3 \pm 29.9$ & $686.8 \pm 25.9$ & $>0.05$ \\
\hline
\end{tabular}

Note: The data presented as an absolute number and a percentage, or as a mean and standard deviations. WBC - white blood cells, ESR erythrocyte sedimentation rate, CRP - C-reactive protein, PT - prothrombin time index. ${ }^{*} p<0.05-$ compared to the group of patients with mild and moderate course of the disease. 


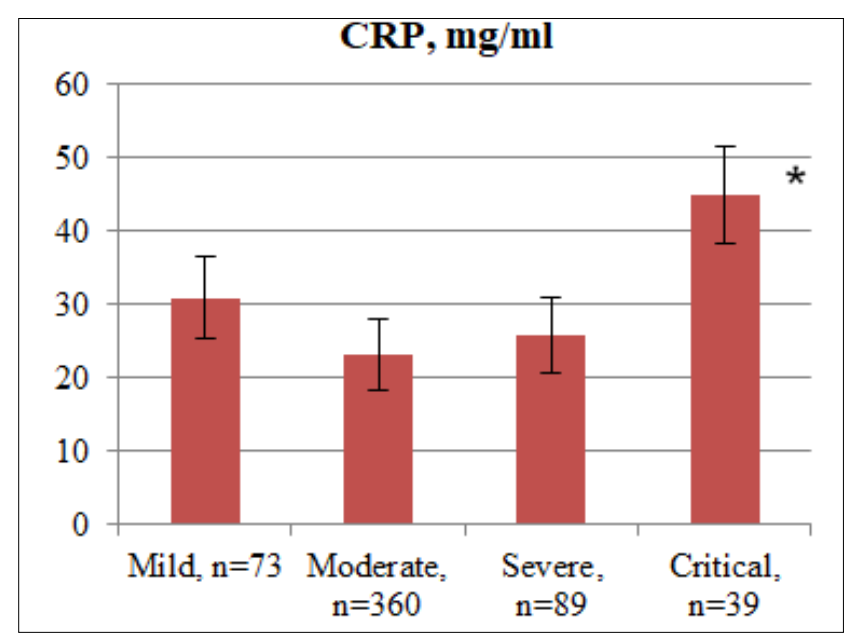

(a)

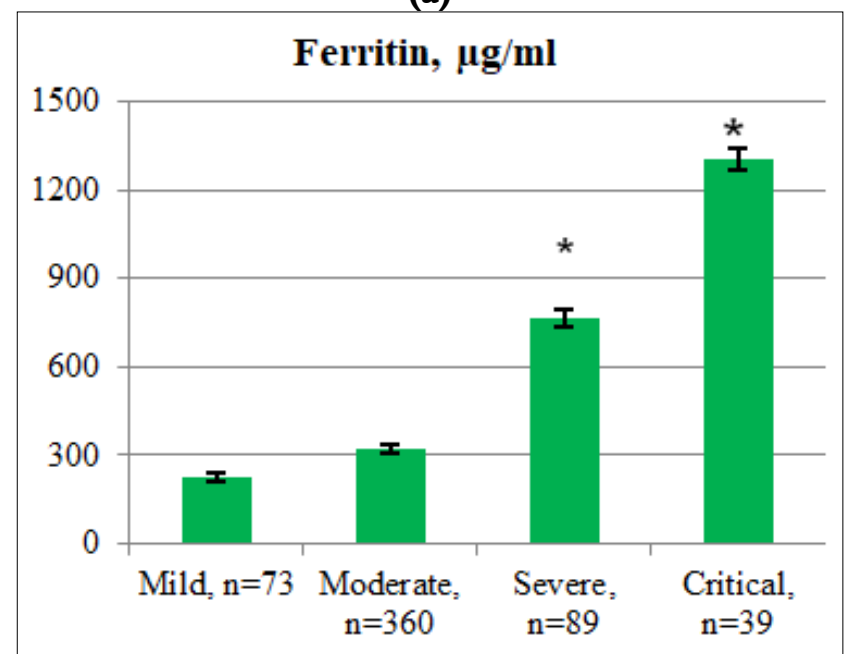

(b)

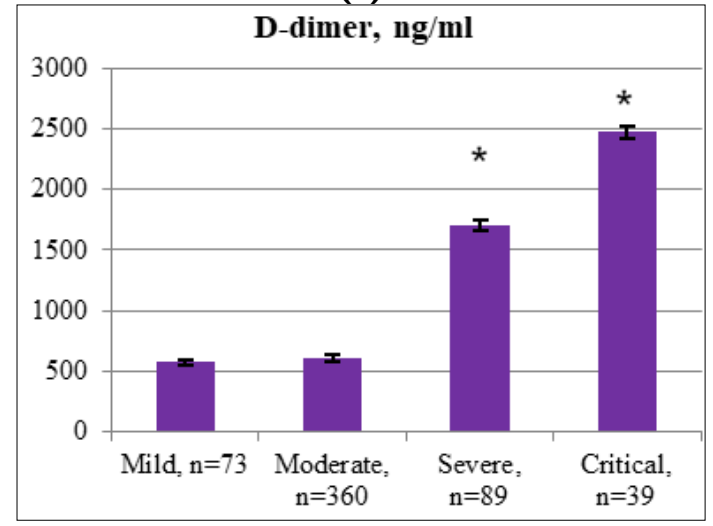

(c)

Figure 3(a),(b),(c).Initial Values of C-reactive protein, Ferritin and D-dimer in Blood Plasma in Patients.

The Data are Presented as a Mean and Standard

Deviations. ${ }^{*} \mathbf{p}<0.05$ - Compared to the Group of Patients with Mild and Moderate Disease

\section{Discussion}

We evaluated the predictors of severe course and mortality at COVID-19 in this study. Among such factors, age seems to be the most decisive. Other studies found that the average age of the deceased patients was 68 years, and they were significantly older than the recovered patients. ${ }^{6}$ Besides, $80 \%$ of COVID-19-related deaths occurred in adults aged $\geq 65$ years. Thus, it was found that old age is a risk factor for mortality from COVID-194, 7, which is consistent with the results of this study. Similar results were previously obtained in patients infected with SARS and MERS. ${ }^{8,9}$ Old aged patients are likely to have a weaker immune response; therefore, they are more likely to develop severe respiratory disorders and ARDS mortality. ${ }^{10}$ In elderly patients, age - related defects in T-and B-lymphocyte function were found in addition to a marked decrease in cell-mediated immune function and a decrease in humoral immune function. Increased production of type 2 cytokines can weaken the control of viral replication and cause longer proinflammatory reactions. ${ }^{11}$

It was reported in the literature that men have a higher mortality rate than women. ${ }^{12-14}$ It was found that among the recovered men were less common than in the group of the deceased. ${ }^{6}$ The higher mortality rate was attributed to higher rates of chronic comorbidities among men, such as cardiovascular disease, hypertension and lung disease, as well as higher smoking rates. ${ }^{12}$ Other studies have explained the sex difference in COVID-19 mortality by a higher expression of the angiotensin converting enzyme receptor (ACE2), which was found in Asian men. ${ }^{15}$ SARS-CoV and SARS-CoV-2 bind to ACE2 receptors in host pneumocytes. ${ }^{16}$

It has been reported that the presence of chronic comorbidities in patients is associated with a severe course of COVID-19 ${ }^{17}$, in particular, cardiovascular diseases and metabolic disorders. ${ }^{18}$ Diabetes mellitus contributes to a more severe course, the development of ARDS with a high mortality rate. High mortality is associated with a violation of innate immunity, which is the first line of defense against SARS-CoV-2, ${ }^{19}$ chronic inflammation or increased coagulation activity in patients with DM. ${ }^{20}$ Treatment of diabetes and hypertension with angiotensin-converting enzyme inhibitors and angiotensin receptor antagonists (ARA) has been shown to increase the expression of ACE2, which therefore increases the risk of severe and fatal COVID-19. ${ }^{16}$ On the other hand, ACE and ARAs have been reported to reduce mortality and the rate of transfer to invasive ventilator in patients with viral pneumonia, as they reduce the inflammatory response by reducing cytokines. However, there is no evidence that ACE inhibitors or ARAs affect the risk of mortality from COVID-19 in combination with cardiovascular disease. ${ }^{21}$

Patients with COVID-19 who had a history of cardiovascular disease ${ }^{22}$ or chronic obstructive pulmonary disease (COPD) ${ }^{23}$ had a higher risk of death. In our study, $63 \%$ of patients with a mild course of the disease and $90 \%$ of patients 
with an extremely severe course were with concomitant pathologies.

The leukocyte count in patients with COVID-19 is important for predicting the severity of the disease. Data from numerous studies show that compared to patients with mild disease, patients with severe disease have a lower granulocyte quantity. ${ }^{24}$ However, in our study, the number of neutrophilic leukocytes was higher in patients with severe course. The authors also associate the severity of COVID-19 with the degree of lymphopenia, in which the percentage of lymphocytes in the blood is inversely proportional to the severity and prognosis, ${ }^{25}$ which is confirmed by the results of this study. On the other hand, an increase in the number of basophils and neutrophils probably predicts a severe course. ${ }^{26}$ In a study involving 81 patients, individuals with an increased neutrophil-lymphocyte ratio (>9.8) had a higher frequency of ARDS and a higher frequency of both non-invasive and invasive mechanical ventilation. ${ }^{27}$

Studies show that in patients with severe COVID-19 hypercoagulation is developed, which leads to excessive fibrin polymerization and an increased risk of thrombosis. ${ }^{28,29}$ The literature describes cases of coagulation disorders and stroke in patients, which suggests that markers of thrombosis may have prognostic value even in younger patients. ${ }^{30,31}$ Elevated D-dimer levels indicates increased thrombin formation and fibrinolysis and are a prognostically unfavorable sign in COVID-19, which has led clinicians to suggest that elevated $\mathrm{D}$-dimer concentrations indicate existing concomitant venous thromboembolism that may lead to ventilation-perfusion disorders..$^{32,33}$ Some researchers have suggested using D-dimer levels in the blood to sort patients. ${ }^{34}$ The results of the study of 343 patients showed that patients with the level of D-dimer $\geq$ $2.0 \mu \mathrm{g} / \mathrm{mL}$ at admission significantly more often died than patients whose rate was $<2.0 \mu \mathrm{g} / \mathrm{mL} .{ }^{35}$ In another study, initial D-dimer level at admission was greater than $1.0 \mu \mathrm{g} /$ $\mathrm{mL}$ and was associated with higher in-hospital mortality. ${ }^{4} \mathrm{It}$ was shown that changes in other markers of blood clotting (thrombocytopenia and prolongation of prothrombin time) were also associated with an increased risk of death at COVID-19. ${ }^{36,37}$ In addition, it has been shown that the recovery of platelets quantity during hospitalization can be a predictor of a positive outcome of the disease. ${ }^{38}$ Our analysis confirmed the role of the D-dimer in predicting negative outcomes.

We have not studied the role of viral load in disease severity. According to published literature data, a higher viral load was found in older patients with COVID-19. However, the difference in mean viral load between severe and mild cases was not significant, ${ }^{39}$ while high initial viral load was associated with death in patients infected with SARS-CoV. ${ }^{40}$
This study had some methodological limitations due to the fact that it is single-center and reflects only retrospective data. The reported mortality rate may not reflect the actual percentage due to the exclusion of patients still receiving treatment, as well as the uneven distribution of reported cases among COVID centers in the Republic.

\section{Conclusion}

Among patients with severe and critical COVID-19, male patients, elderly patients, patients with hypertension and diabetes mellitus were more often noted. This allows us to conclude that these parameters may be risk factors for severe and critical disease and death. Also, initial leukocytosis, lymphopenia, high levels of D-dimer and ferritin are associated with severe disease and mortality. Additional attention should be paid to these factors, and further assessments should be conducted to explore the mechanisms underlying these effects.

\section{Author Contributions}

Conceptualization V.S., A. Abdurakhmanov; methodology and validation, A. Abdurakhmanov; data collection, Khan A., N.I.; writing-original draft preparation, A. Abdurakhmanov; writing-review and editing, V.S. and A. Alimov; supervision, V.S. All authors have read and agreed to the published version of the manuscript.

\section{Institutional Review Board Statement}

The study was conducted according to the guidelines of the Declaration of Helsinki, and approved by the Institutional Review Board of Republican Research Centre of Emergency Medicine.

\section{Acknowledgments}

This work is supported by Ministry of Health and Ministry of Innovative Development of the Republic of Uzbekistan (grant number A-CC-2021-112/2).

\section{Conflicts of Interest: None}

\section{References}

1. Coronavirus (COVID-19) Information and Updates - John Hopkins Medicine. Available from: www. hopkinsmedicine.org/coronavirus/.

2. Vetter $P, V u$ DL, L'Huillier AG, Schibler $M$, Kaiser $L$, Jacquerioz F. Clinical features of COVID-19. BMJ. 2020 Apr;369:m1470. [PubMed] [Google Scholar]

3. Jordan RE, Adab P, Cheng KK. Covid-19: risk factors for severe disease and death. BMJ. 2020 Mar;368:m1198. [PubMed] [Google Scholar]

4. Zhou F, Yu T, Du R, Fan G, Liu Y, Liu Z, Xiang J, Wang Y, Song B, Gu X, Guan L, Wei Y, Li H, Wu X, Xu J, Tu S, Zhang $Y$, Chen $H, C a o B$. Clinical course and risk factors for mortality of adult inpatients with COVID-19 in 
Wuhan, China: a retrospective cohort study, Lancet. 2020 Mar;395(10229):1054-62. [PubMed] [Google Scholar]

5. What you need to know about coronavirus infections (COVID-19)? Ministry of Health, the Republic of Uzbekistan. Available from: https://coronavirus.uz/ru.

6. Chen T, Wu D, Chen H, Yan W, Yang D, Chen G, Ma K, Xu D, Yu H, Wang H, Wang T, Guo W, Chen J, Ding C, Zhang X, Huang J, Han M, Li S, Luo X, Zhao J, Ning Q. Clinical characteristics of 113 deceased patients with coronavirus disease 2019: retrospective study. BMJ. 2020 Mar;368:m1091. [PubMed] [Google Scholar]

7. CDC COVID-19 Response Team. Severe outcomes among patients with coronavirus disease 2019 (COVID-19). MMWR Morb Mortal Wkly Rep. 2020 Mar;69(12):3436. [PubMed] [Google Scholar]

8. Hong KH, Choi JP, Hong SH, Lee J, Kwon JS, Kim SM, Park SY, Rhee JY, Kim BN, Choi HJ, Shin EC, Pai H, Park SH, Kim $\mathrm{SH}$. Predictors of mortality in Middle East respiratory syndrome (MERS). Thorax. 2018 Mar;73(3):286-9. [PubMed] [Google Scholar]

9. Choi KW, Chau TN, Tsang O, Tso E, Chiu MC, Tong WL, Lee PO, Ng TK, Ng WF, Lee KC, Lam W, Yu WC, Lai JY, Lai ST; Princess Margaret Hospital SARS Study Group. Outcomes and prognostic factors in 267 patients with severe acute respiratory syndrome in Hong Kong, Ann Intern Med. 2003 Nov;139(9):715-23. [PubMed] [Google Scholar]

10. Wu C, Chen X, Cai Y, Xia J, Zhou X, Xu S, Huang H, Zhang L, Zhou X, Du C, Zhang Y, Song J, Wang S, Chao Y, Yang Z, Xu J, Zhou X, Chen D, Xiong W, Xu L, Zhou F, Jiang J, Bai C, Zheng J, Song Y. Risk factors associated with acute respiratory distress syndrome and death in patients with coronavirus disease 2019 pneumonia in Wuhan, China. JAMA Intern Med. 2020 Jul;180(7):93443. [PubMed] [Google Scholar]

11. Opal SM, Girard TD, Ely EW. The immunopathogenesis of sepsis in elderly patients. Clin Infect Dis. 2005 Nov;41 Suppl 7:S504-12. [PubMed] [Google Scholar]

12. The Lancet. The gendered dimensions of COVID-19. The Lancet. 2020 Apr;395(10231):1168. [PubMed] [Google Scholar]

13. Wenham C, Smith J, Morgan R. COVID-19: the gendered impacts of the outbreak. Lancet. 2020 Mar;395(10227):846-8. [PubMed] [Google Scholar]

14. Cai H. Sex difference and smoking predisposition in patients with COVID-19. Lancet Respir Med. 2020 Apr;8(4):e20. [PubMed] [Google Scholar]

15. Zheng QL, Duan T, Jin LP. Single-cell RNA expression profiling of ACE2 and AXL in the human maternal-fetal interface. Reprod Dev Med. 2020;4(1):7-10. [Google Scholar]

16. Fang L, Karakiulakis G, Roth M. Are patients with hypertension and diabetes mellitus at increased risk for COVID-19 infection? Lancet Respir Med. 2020 Apr;8(4):e21. [PubMed] [Google Scholar]

17. Zhang JJ, Chen BS, Dai HQ, Ren JW, Zhou LW, Wu $\mathrm{SH}$, Liu HW. Clinical characteristics of 140 patients infected with SARS-CoV-2 in Wuhan, China. Allergy. 2020 Jul;75(7):1730-41. [PubMed] [Google Scholar]

18. Li B, Yang J, Zhao F, Zhi L, Wang X, Liu L, Bi Z, Zhao Y. Prevalence and impact of cardiovascular metabolic diseases on COVID-19 in China. Clin Res Cardiol. 2020 May;109(5):531-8. [PubMed] [Google Scholar]

19. Pal R, Bhansali A. COVID-19, Diabetes Mellitus and ACE2: The conundrum. Diabetes Res Clin Pract. 2020 Apr;162:108132. [PubMed] [Google Scholar]

20. Hussain A, Bhowmik B, Cristina do Vale Moreira $N$. COVID-19 and diabetes: Knowledge in progress. Diabetes Res Clin Pract. 2020 Apr;162:108142. [PubMed] [Google Scholar]

21. Peng YD, Meng K, Guan HQ, Leng L, Zhu RR, Wang BY, He MA, Cheng LX, Huang K, Zeng QT. Clinical characteristics and outcomes of 112 cardiovascular disease patients infected by 2019-nCoV. Zhonghua Xin Xue Guan Bing Za Zhi. 2020 Jun;48(6):450-5. [PubMed] [Google Scholar]

22. Aggarwal G, Cheruiyot I, Aggarwal S, Wong J, Lippi G, Lavie CJ, Henry BM, Sanchis-Gomar F. Association of cardiovascular disease with coronavirus disease 2019 (COVID-19) Severity: a meta-analysis. Curr Probl Cardiol. 2020 Aug;45(8):100617. [PubMed] [Google Scholar]

23. Alqahtani JS, Oyelade T, Aldhahir AM, Alghamdi SM, Almehmadi M, Alqahtani AS, Quaderi S, Mandal S, Hurst JR. Prevalence, severity and mortality associated with COPD and smoking in patients with COVID-19: a rapid systematic review and meta-analysis. PLoS One. 2020 May;15(5):e0233147. [PubMed] [Google Scholar]

24. Guan WJ, Ni ZY, Hu Y, Liang WH, Ou CQ, He JX, Liu $L$, Shan H, Lei CL, Hui DSC, Du B, Li LJ, Zeng G, Yuen KY, Chen RC, Tang CL, Wang T, Chen PY, Xiang J, Li SY, Wang JL, Liang ZJ, Peng YX, Wei L, Liu Y, Hu YH, Peng P, Wang JM, Liu JY, Chen Z, Li G, Zheng ZJ, Qiu SQ, Luo J, Ye CJ, Zhu SY, Zhong NS; China Medical Treatment Expert Group for Covid-19. Clinical characteristics of coronavirus disease 2019 in China. N Engl J Med. 2020 Apr;382(18):1708-20. [PubMed] [Google Scholar]

25. Tan $C$, Huang $Y$, Shi F, Tan $K$, Ma $Q$, Chen $Y$, Jiang $X$, Li X. C-reactive protein correlates with computed tomographic findings and predicts severe COVID-19 early. J Med Virol. 2020 Jul;92(7):856-62. [PubMed] [Google Scholar]

26. Chen $R$, Sang $L$, Jiang $M$, Yang $Z$, Jia $N, F u$, Xie J, Guan W, Liang W, Ni Z, Hu Y, Liu L, Shan H, Lei C, Peng Y, Wei L, Liu Y, Hu Y, Peng P, Wang J, Liu J, Chen Z, Li G, Zheng Z, Qiu S, Luo J, Ye C, Zhu S, Zheng J, Zhang N, Li $\mathrm{Y}, \mathrm{He}$ J, Li J, Li S, Zhong N; Medical Treatment Expert 
Group for COVID-19. Longitudinal hematologic and immunologic variations associated with the progression of COVID-19 patients in China. J Allergy Clin Immunol. 2020 Jul;146(1):89-100. [PubMed] [Google Scholar]

27. Ma A, Cheng J, Yang J, Dong M, Liao X, Kang Y. Neutrophilto-lymphocyte ratio as a predictive biomarker for moderate-severe ARDS in severe COVID-19 patients. Crit Care. 2020 Jun;24(1):288. [PubMed] [Google Scholar]

28. Spiezia L, Boscolo A, Poletto F, Cerruti L, Tiberio I, Campello E, Navalesi P, Simioni P. COVID-19-related severe hypercoagulability in patients admitted to intensive care unit for acute respiratory failure. Thromb Haemost. 2020 Jun;120(6):998-1000. [PubMed] [Google Scholar]

29. Pavoni V, Gianesello L, Pazzi M, Stera C, Meconi T, Frigieri FC. Evaluation of coagulation function by rotation thromboelastometry in critically ill patients with severe COVID-19 pneumonia. J Thromb Thrombolysis. 2020 Aug;50(2):281-6. [PubMed] [Google Scholar]

30. Oxley TJ, Mocco J, Majidi S, Kellner CP, Shoirah H, Singh IP, De Leacy RA, Shigematsu T, Ladner TR, Yaeger KA, Skliut M, Weinberger J, Dangayach NS, Bederson JB, Tuhrim S, Fifi JT. Large-vessel stroke as a presenting feature of Covid-19 in the young. N Engl J Med. 2020 May;382(20):e60. [PubMed] [Google Scholar]

31. Xiong W, Mu J, Guo J, Lu L, Liu D, Luo J, Li N, Liu J, Yang $D$, Gao $H$, Zhang $Y$, Lin $M$, Shen $S$, Zhang $H$, Chen $L$, Wang G, Luo F, Li W, Chen S, He L, Sander JW, Zhou D. New onset neurologic events in people with COVID-19 infection in three regions in China. Neurology. 2020 Sep;95(11):e1479-87. [PubMed] [Google Scholar]

32. Cummings MJ, Baldwin MR, Abrams D, Jacobson SD, Meyer BJ, Balough EM, Aaron JG, Claassen J, Rabbani LE, Hastie J, Hochman BR, Salazar-Schicchi J, Yip NH, Brodie D, O'Donnell MR. Epidemiology, clinical course, and outcomes of critically ill adults with COVID-19 in New York City: a prospective cohort study. Lancet. 2020 Jun;395(10239):1763-70. [PubMed] [Google Scholar]

33. Tang N, Li D, Wang X, Sun Z. Abnormal coagulation parameters are associated with poor prognosis in patients with novel coronavirus pneumonia. J Thromb Haemost. 2020;4(18):844-7. [PubMed] [Google Scholar]

34. Li C, Hu B, Zhang Z, Qin W, Zhu Z, Zhai Z, Davidson BL, Wang C. D-dimer triage for COVID-19. Acad Emerg Med. 2020 Jul;27(7):612-3. [PubMed] [Google Scholar]

35. Zhang L, Yan X, Fan Q, Liu H, Liu X, Liu Z, Zhang Z. $D$-dimer levels on admission to predict in-hospital mortality in patients with COVID-19. J Thromb Haemost. 2020 Jun;18(6):1324-9. [PubMed] [Google Scholar]

36. Henry BM, de Oliveira MHS, Benoit S, Plebani M, Lippi G. Hematologic, biochemical and immune biomarker abnormalities associated with severe illness and mortality in coronavirus disease 2019 (COVID-19): a meta-analysis. Clin Chem Lab Med. 2020 Jun;58(7):1021-8. [PubMed] [Google Scholar]

37. Levi $M$, Thachil J, Iba T, Levy JH. Coagulation abnormalities and thrombosis in patients with COVID-19. Lancet Haematol. 2020 Jun;7(6):e438-40. [PubMed] [Google Scholar]

38. Chen R, Sang L, Jiang M, Yang Z, Jia N, Fu W, Xie J, Guan W, Liang W, Ni Z, Hu Y, Liu L, Shan H, Lei C, Peng Y, Wei L, Liu Y, Hu Y, Peng P, Wang J, Liu J, Chen Z, Li G, Zheng Z, Qiu S, Luo J, Ye C, Zhu S, Zheng J, Zhang N, Li $\mathrm{Y}, \mathrm{He}$ J, Li J, Li S, Zhong N; Medical Treatment Expert Group for COVID-19. Longitudinal hematologic and immunologic variations associated with the progression of COVID-19 patients in China. J Allergy Clin Immunol. 2020 Jul;146(1):89-100. [PubMed] [Google Scholar]

39. To KK, Tsang OT, Leung WS, Tam AR, Wu TC, Lung DC, Yip CC, Cai JP, Chan JM, Chik TS, Lau DP, Choi CY, Chen LL, Chan WM, Chan KH, Ip JD, Ng AC, Poon RW, Luo CT, Cheng VC, Chan JF, Hung IF, Chen Z, Chen $\mathrm{H}$, Yuen KY. Temporal profiles of viral load in posterior oropharyngeal saliva samples and serum antibody responses during infection by SARS-CoV-2: an observational cohort study. Lancet Infect Dis. 2020 May;20(5):565-74. [PubMed] [Google Scholar]

40. Chu CM, Poon LL, Cheng VC, Chan KS, Hung IF, Wong MM, Chan KH, Leung WS, Tang BS, Chan VL, Ng WL, Sim TC, Ng PW, Law KI, Tse DM, Peiris JS, Yuen KY. Initial viral load and the outcomes of SARS. CMAJ. 2004 Nov;171(11):1349-52. [PubMed] [Google Scholar] 